\title{
Spawning migration of Labeobarbus species to some tributary rivers of Lake Tana, Ethiopia
}

\author{
Gizachew Teshome ${ }^{1 *}$, Abebe Getahun ${ }^{2}$, Minwyelet Mingist ${ }^{3}$ and Wassie Anteneh ${ }^{4}$
}

\author{
${ }^{1}$ Semera University, College of Natural Sciences, Department of Biology, P.O.Box 135, Semera, Ethiopia \\ ${ }^{2}$ Addis Ababa University, College of Natural Sciences, Department of Zoological Sciences P.O.Box 1176, Addis Ababa, \\ Ethiopia \\ ${ }^{3}$ Bahir Dar University, College of Agriculture and Environmental Science, Department of Fisheries, Wetlands and Wildlife \\ Management, P.O.Box 79, Bahir Dar, Ethiopia \\ ${ }^{4}$ Bahir Dar University, College of Science, Department of Biology, P.O.Box 79, Bahir Dar, Ethiopia
}

\begin{abstract}
Spawning migration of Labeobarbus species was studied from August to December 2013 in some tributary rivers (Qimon, Guanta, Shini, and Chibirna) of Lake Tana. Fish specimens and physico-chemical parameters were measured bimonthly in August and September but monthly from October to December. Adult fish specimens were caught using 6 and $8 \mathrm{~cm}$ stretched mesh size monofilament gillnets and 6, 8, 10 and $12 \mathrm{~cm}$ mesh size multifilament gillnets. A total of 933 adult Labeobarbus specimens were collected during the study period. Labeobarbus intermedius was the most abundant species followed by L. brevicephalus. The peak spawning season of L. intermedius was from fourth week of August to end of September and for L. brevicephalus it was from fourth week of August to beginning of October. Both species were found to spawn in all sampling rivers. However L. truttiformis spawned only at Guanta and Qimon Rivers during August while $L$. nedgia in Shini and Chibirna Rivers at the end of September. This implies the presence of micro-spatial segregation among species. Pair-wise comparison of Labeobarbus species showed temporal segregation in all sampling months, except $L$. brevicephalus and $L$. nedgia. The present findings showed that small tributary rivers and streams are the main spawning grounds for Labeobarbus species of Lake Tana. Therefore, main spawning grounds or routes should be protected from the deleterious effects of anthropogenic activities like illegal fishing, irrigation and sand mining for wise use of the fish resources.
\end{abstract}

Key words: Fecundity, Fish, Migration, River, Spawning

DOI: http://dx.doi.org/10.4314/ejst.v8i1.4

\section{INTRODUCTION}

Ethiopia is rich in its fish fauna, having a diversified species in the inland water bodies (Abebe Getahun, 2002). The three major fish families (Cichlidae, Clariidae and Cyprinidae) are widely distributed throughout the country. In Lake Tana, Cyprinidae is the largest family and is represented by four genera. These are the genera Barbus represented by three species: $B$. humilis, B. pleurograma, and B. tanapelagious (Eshete Dejen et al., 2003), Varicorhinus represented by one specie: V. beso, Garra represented by four species: G. dembecha, G. tana, G. regressus and G. small mouth (Akewake Geremew, 2007) and Labeobarbus, which is the most abundant genus of the family and consists of 17 species forming a unique species flock in Lake Tana (Nagelkerke, 1997).
The reproductive biology Labeobarbus species of Lake Tana is more or less similar to Barbus holubi, $B$. kimberleyensis, Labeo capensis and L. umbratus which are found in a large reservoir on the Orange River, South Africa (Tomasson et al., 1984). In continuously flowing regulated rivers, time of spawning is governed by water temperatures and fish have moderate fecundity; large eggs, incubation time of several days and the larvae are initially immobile with large yolk sacs (Tomasson et al., 1984).

The single annual upstream migration reproductive strategy of Lake Tana Labeobarbus species make them highly vulnerable as fishers target the spawning aggregations (Skelton et al., 1991). The most plausible explanation for the decline of the Labeobar-

\footnotetext{
*Corresponding author: gizachew2006@gmail.com

(C) This is an Open Access article distributed under the terms of the Creative Commons Attribution License (http://creativecommons.org/licenses/CC BY4.0)
} 
bus stock in Lake Tana is thought to be recruitment overfishing by the commercial gillnet fishery that targets the riverine spawners (de Graaf et al., 2004) and poisoning of the spawning stock in rivers using the crushed seeds of Birbira (Milletia ferruginea) (Nagelkerke and Sibbing, 1996).

Many recent studies have shown that Lake Tana tributary rivers are severely degraded by different developmental activities like irrigation and sand mining. In so far as we know, there is no any study dealing with the importance of the present small tributary rivers and streams of Lake Tana as the main spawning grounds for some endemic Labeobarbus species. Thus, this study aims at investigating the spawning migration fish species to these unexplored tributary rivers of Lake Tana.

\section{MATERIALS AND METHODS}

\section{Description of the study area}

Lake Tana is the largest lake and situated in the northwest of Ethiopia, at an altitude of $1830 \mathrm{~m}$ with a surface area of $3200 \mathrm{~km}^{2}$ and a watershed of 16500 $\mathrm{km}^{2}$ (Rzóska, 1976). More than 60 small seasonal tributaries and seven permanent rivers (Gumara, Ribb, Megech, Gilgel Abbay, Gelda, Arno-Garno and Dirma) feed the lake. Gumara is one of the largest perennial rivers flowing into Lake Tana and arises from the western side of Gunna Mountain peaks. It has a number of tributary rivers and streams namely: Dukalit, Kizin, Wonzema, Bawaza and Guanta.

A number of tributary rivers join the main Ribb River such as Chibirna, Shini, Kirarign, Keha, Barya, Hamus and Melo Rivers. Shini River is located at $12^{\circ} 05.906^{\prime} \mathrm{N}$ and $37^{\circ} 45.702^{\prime} \mathrm{E}$, and Chibirna River is also located at $12^{\circ} 04.402^{\prime} \mathrm{N}$ and $37^{\circ} 44.075^{\prime} \mathrm{E}$. In Shini River, sand mining is common activity and there is also small scale irrigation. Shini and Chibirna Rivers confluence at Bura Egziabher Kebele before entering to Ribb River. Both Rivers dry out during the dry season due to excessive withdrawal of water for small irrigation.

Qimon River is located in northeastern part of Lake Tana at $12^{\circ} 11.000^{\prime} \mathrm{N}$ and $37^{\circ} 34.587^{\prime} \mathrm{E}$. This river is starting from Kulkual Ber watershed in Gondar Zuria district and the upstream part of the river watershed is covered by dense forest, gravel beds. Qimon River is characterized by dense forest in the upper part of the river and the mouth of this river is also densely covered by shrubs, grass, and water hyacinth. Guanta River is characterized by dense vegetation. Figure 1 shows the specific sampling sites at the tributary rivers of Lake Tana.

\section{Field sampling and type of data}

\section{Abiotic parameters}

Physico-chemical parameters were measured in all sampling sites of spawning rivers. Water quality parameters like conductivity, $\mathrm{pH}$, temperature and total dissolved solids (TDS) were measured using Cond/ TDS meter (Wagtech Int., Model CE 470 Cond Meter 01189) and dissolved oxygen using oxygen meter (Wagtech Int., Model CO-411). Water transparency (secchi depth) of the rivers was estimated with a standard Secchi Disc of $25 \mathrm{~cm}$ diameter.

\section{Gillnet setting and species identification}

Sampling sites were selected based on the suitability for gillnet setting and human interference. In all sampling sites of the tributary rivers of Lake Tana, gillnet was set during the day time and sampling of fish was conducted usually from 10:00 am to 3:00 pm. Multifilament gillnets with $6,8,10$ and $12 \mathrm{~cm}$ stretched mesh size and monofilament gillnets with 4 and $6 \mathrm{~cm}$ mesh size were used for collecting fish specimens. After capture, the collected specimens of Labeobar- 


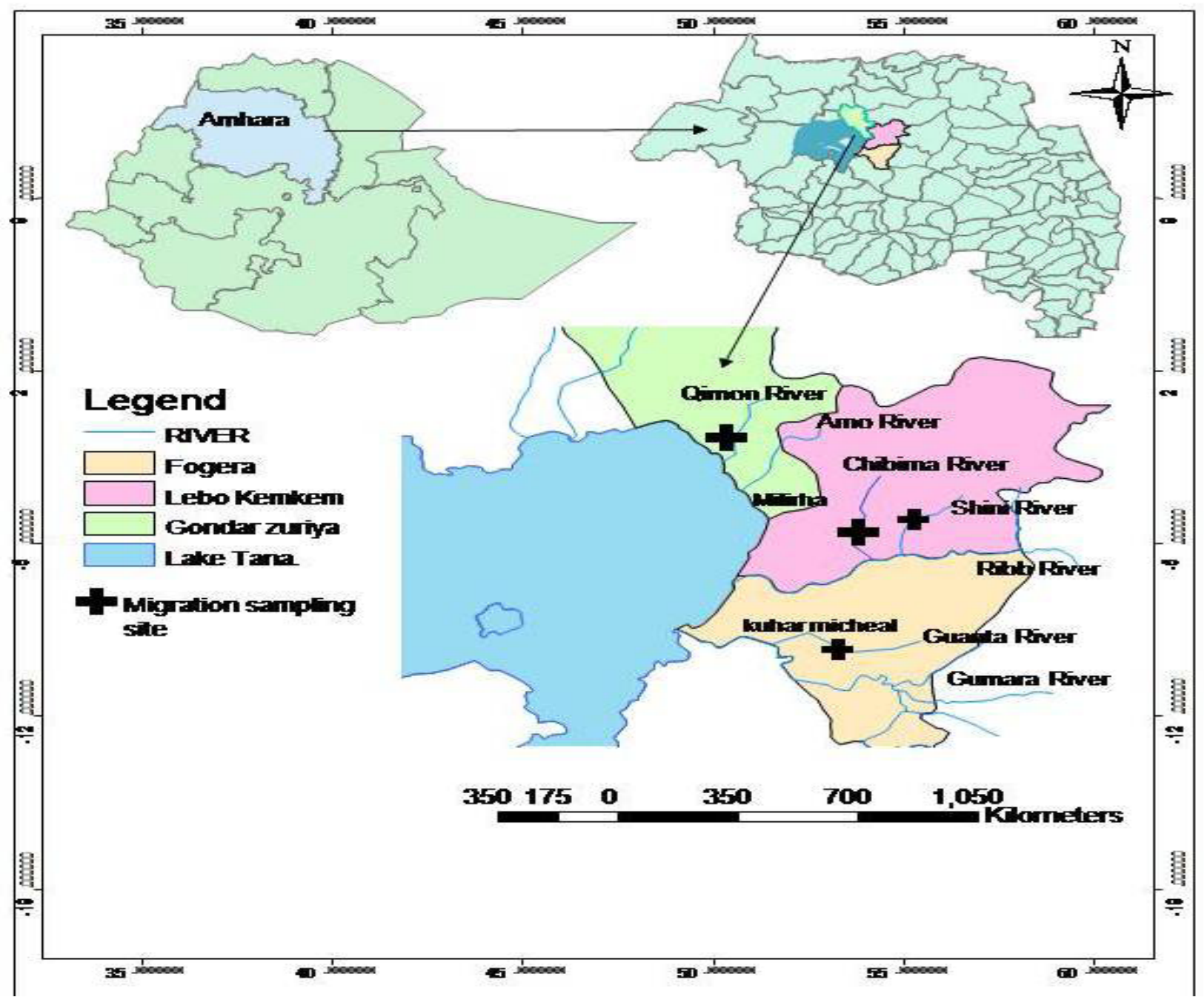

Figure 1. Map of Ethiopia, Amhara, Lake Tana and sampling sites at some inflowing rivers (own map).

bus species were identified to species level using keys developed by Nagelkerke (1997), and Nagelkerke and Sibbing (2000). Then, the specimens' total length, fork length, standard length and total weight were measured to the nearest $0.1 \mathrm{~cm}$ and $0.1 \mathrm{~g}$ precision for length and weight, respectively. After dissection, gonadal maturities of each fish specimen were identified using seven point maturity scales (Nagelkerke, 1997). Gonad weight was measured to the nearest $0.1 \mathrm{~g}$ using sensitive balance.

\section{Relative abundance and fish composition}

Index of Relative Importance (IRI) is a measure of the relative abundance or commonness of the species based on number and weight of individuals in catches as well as their frequency of occurrence (Kold- ing, 1999). IRI was used to find the most important species in terms of number, weight and frequency of occurrence in the catches from the different sampling sites. IRI gives a better representation of the ecological importance of species rather than the weight, number frequency of occurrence alone (Sanyanga, 1996).

Percent of IRI was calculated as follows:

$$
\text { IRI }=\frac{(\% \mathrm{Wi}+\% \mathrm{Ni}) \% \mathrm{Fi}}{\sum_{\mathrm{j}=1}^{s=1}(\% \mathrm{Wj}+\% \mathrm{Nj}) \% \mathrm{Fj}} \mathrm{X} 100
$$

Where, $\% \mathrm{Wi}$ and $\% \mathrm{Ni}$ are percentage weight and number of each species of total catch, respectively; $\% \mathrm{Fi}$ is percentage frequency of occurrence of each species in total number of settings. $\mathrm{S}$ is total number 
of species. $\% \mathrm{~W}_{\mathrm{j}}$ and $\% \mathrm{~N}_{\mathrm{j}}$ are percentage weight and number of total species of total catch, respectively. $\% \mathrm{~F}_{\mathrm{j}}$ is percentage frequency of occurrence of total species in total number of setting.

\section{Gonado-Somatic Index (GSI) and fecundity}

GSI is the ratio of fish gonad weight to body weight and used to determine the peak time of reproductive season of spawning migratory species. The GSI was determined using the following formula:

GSI $=\frac{\text { Gonad weight }(\mathrm{g})}{\text { Body weight }(\mathrm{g})} * 100$

Eggs from the ripe female fish were preserved with $8 \%$ formalin for fecundity estimation. Three sub-samples of $1 \mathrm{~g}$ eggs were taken from different parts of ovary and counted and the average was calculated. The total number of eggs per ovary was calculated by extrapolation from the mean calculated. The correlation of fecundity with fork length, total weight and ovary weight were made to determine the relationship of fecundity with morphometric measurements. Fecundity was determined based on fork length and gonad weight. These two formulas were indicated as follows:
$\mathrm{F}=\mathrm{aFL} \mathrm{b}^{\mathrm{b}}, \quad$ Where $\mathrm{F}-$ fecundity, $\mathrm{FL}-$ fork length; $\mathrm{a}$-constant and $\mathrm{b}$ - exponent

$\mathrm{F}=\mathrm{aGW}{ }^{\mathrm{b}}$, where $\mathrm{GW}-$ gonad weight

\section{Data analysis}

Data analysis was made using Statistical Package for Social Science Students (SPSS Inc., software version 20.0), SASS version 9.2 and Microsoft Excel. Physico-chemical parameters of water were performed using one way ANOVA. For all ANOVA test, mean comparison was performed using post hoc (LSD) to identify the difference between each parameter among sampling sites. Presence or absence of spatial and temporal segregation patterns of Labeobarbus species in all sampling rivers was also analyzed using $\mathrm{x}^{2} \mathrm{rXc}$ contingency table.

\section{RESULTS}

\section{Abiotic parameters}

The analysis for temperature, TDS, conductivity and Secchi depth showed significant differences among the different rivers $(\mathrm{p}<0.05)$. Mean comparison of all physico-chemical parameters showed significant difference between Guanta River and other sampling rivers (Table 1).

Table 1. Water quality parameters in the sampling sites (Mean \pm S.E).

\begin{tabular}{lllllll}
\hline River & $\begin{array}{l}\text { Oxygen } \\
\left(\mathrm{mgl}^{-1}\right)\end{array}$ & $\begin{array}{l}\text { Temperature } \\
\left({ }^{\circ} \mathrm{C}\right)\end{array}$ & $\begin{array}{l}\text { Conductivity } \\
\left.(\mu \mathrm{s} \mathrm{cm})^{-1}\right)\end{array}$ & $\begin{array}{l}\text { Total dissolved } \\
\text { solids } \\
(\mathrm{ppm})\end{array}$ & $\mathrm{pH}$ & $\begin{array}{l}\text { Secchi depth } \\
(\mathrm{cm})\end{array}$ \\
\hline Chibirna & $6.5 \pm 0.44$ & $22.1 \pm 0.63^{\mathrm{a}}$ & $313.1 \pm 27.19^{\mathrm{a}}$ & $214.3 \pm 19.24^{\mathrm{a}}$ & $8.1 \pm 0.13$ & $82.1 \pm 7.78^{\mathrm{a}}$ \\
Shini & $6.5 \pm 0.54$ & $20.8 \pm 1.02^{\mathrm{cb}}$ & $239.5 \pm 10.12^{\mathrm{b}}$ & $162.9 \pm 7.07^{\mathrm{b}}$ & $8.2 \pm .14$ & $73.3 \pm 9.52^{\mathrm{ba}}$ \\
Overall & $6.2 \pm 0.24$ & $20.9 \pm 0.40$ & $235.4 \pm 14.40$ & $159.4 \pm 10.20$ & $8.2 \pm 0.08$ & $65.9 \pm 5.30$ \\
mean & 0.52 & 0.010 & 0.002 & 0.003 & 0.116 & 0.001 \\
\hline
\end{tabular}

The same subscript letters denotes non-significance at 0.05 using LSD mean comparison. 


\section{Species composition and relative abundance}

A total of 1178 fish specimens were collected from Qimon, Guanta, Chibirna, and Shini Rivers. From the total specimens collected, 32.24\% (382), $17.65 \%$ (208), $24.37 \%$ (287) and 25.52\% (301) were sampled/contributed from Chibirna, Guanta, Qimon, and Shini Rivers, respectively. From the whole catch compositions, the genus Labeobarbus contributed 79.2\% (933), $V$. beso $14.67 \%$ (172), $C$. gariepinus 2.4\% (28), and O. niloticus 3.5\% (41). From the total Labeobarbus specimens collected, L. intermedius was the most dominant specie (43\%) followed by L. brevicephalus (23\%), whereas the rest were few in number (Table 2).
The relative abundance and distribution of each species varied among sampling rivers across sampling months (Table 3). Most of the species were sampled in good numbers in the month of September. Among the 933 Labeobarbus specimens, $97 \%$ (905) were from the three dominant species ( $L$. intermedius, L. brevicephalus and L. nedgia). The rest five Labeobarbus species were found rarely in all sampling rivers. In all sampling rivers, $L$. intermedius was the most important specie, followed by either L. brevicephalus or L. nedgia (Table 3).

Table 2. Species composition in all sampling rivers.

\begin{tabular}{lllllll}
\hline Species & Chibirna & Guanta & Qimon & Shini & Total & Percentage \\
\hline L. brevicephalus & 47 & 73 & 126 & 31 & 277 & 23.5 \\
L. crassibarbis & 0 & 0 & 2 & 0 & 2 & 0.2 \\
L. dejeni & 1 & 0 & 0 & 2 & 3 & 0.3 \\
L. intermedius & 189 & 81 & 113 & 124 & 507 & 43 \\
L. megastoma & 0 & 0 & 5 & 0 & 5 & 0.4 \\
L. nedgia & 41 & 0 & 1 & 79 & 121 & 10.3 \\
L. truttiformis & 0 & 5 & 7 & 0 & 12 & 1 \\
L. tsanensis & 0 & 0 & 6 & 0 & 6 & 0.5 \\
V. beso & 90 & 28 & 0 & 54 & 172 & 14.6 \\
Barbus humilis & 2 & 0 & 0 & 0 & 2 & 0.2 \\
C. gariepinus & 7 & 11 & 1 & 9 & 28 & 2.4 \\
G. dembecha & 2 & 0 & 0 & 0 & 2 & 0.2 \\
O. niloticus & 3 & 10 & 26 & 2 & 41 & 3.5 \\
\hline Total & 382 & 208 & 287 & 301 & 1178 & 100.00 \\
\hline
\end{tabular}


Table 3. Percentage index of relative importance (\%IRI) of Labeobarbus species from all sampling rivers.

\begin{tabular}{|c|c|c|c|c|c|c|c|c|c|}
\hline River & Fish species & $\mathrm{N}$ & $\% \mathrm{~N}$ & $\mathrm{~W}$ & $\% \mathrm{~W}$ & $\mathrm{~F}$ & $\% \mathrm{~F}$ & IRI & $\%$ IRI \\
\hline \multirow{7}{*}{ Qimon } & L. intermedius & 113 & 43.46 & 7133.4 & 39.54 & 6 & 100.00 & 8300 & 49.28 \\
\hline & L. brevicephalus & 126 & 48.46 & 7509.1 & 41.63 & 5 & 83.33 & 7507.2 & 44.57 \\
\hline & L. nedgia & 1 & 0.38 & 129.4 & 0.72 & 1 & 16.67 & 18.337 & 1.83 \\
\hline & L. tsanensis & 6 & 2.31 & 1255.4 & 6.96 & 2 & 33.33 & 308.96 & 1.82 \\
\hline & L. truttiformis & 7 & 2.69 & 1207.3 & 6.69 & 3 & 50.00 & 469 & 1.04 \\
\hline & L. megastoma & 5 & 1.92 & 606.9 & 3.36 & 2 & 33.33 & 175.98 & 0.36 \\
\hline & L. crassibarbis & 2 & 0.77 & 195.7 & 1.08 & 2 & 33.33 & 61.66 & 0.36 \\
\hline \multirow{7}{*}{ Chibirna } & Total & 260 & & 18037.2 & & & 100.00 & 16958.75 & 100.00 \\
\hline & L. intermedius & 189 & 67.98 & 1683.1 & 20.18 & 6 & 85.71 & 7555.83 & 46.76 \\
\hline & L. nedgia & 41 & 14.75 & 3631.1 & 43.53 & 6 & 85.71 & 4994.91 & 30.91 \\
\hline & L. brevicephalus & 47 & 16.91 & 2741.5 & 32.86 & 5 & 71.43 & 3555.29 & 22.00 \\
\hline & L. dejeni & 1 & 0.36 & 286.5 & 3.43 & 1 & 14.28 & 54.18 & 0.33 \\
\hline & Total & 278 & 100.00 & 8342.2 & 100.00 & & 100.00 & 16160.21 & 100.00 \\
\hline & L. intermedius & 72 & 48.00 & 7239.7 & 47.98 & 6 & 85.71 & 8226.4 & 59.01 \\
\hline \multirow[t]{3}{*}{ Guanta } & L. brevicephalus & 73 & 48.67 & 3536.1 & 23.43 & 5 & 71.43 & 5150.1 & 36.94 \\
\hline & L. truttiformis & 5 & 3.33 & 2474.3 & 16.40 & 2 & 28.57 & 563.69 & 4.04 \\
\hline & Total & 150 & 100.00 & 15090.3 & 100.00 & & 100.00 & 13940 & 100.00 \\
\hline \multirow[t]{5}{*}{ Shini } & L. intermedius & 124 & 52.54 & 11980.20 & 83.50 & 6 & 100.00 & 13603.86 & 71.84 \\
\hline & L. nedgia & 79 & 33.47 & 365.00 & 2.54 & 5 & 83.33 & 3601.84 & 19.02 \\
\hline & L. brevicephalus & 31 & 13.14 & 1746.80 & 12.17 & 4 & 66.67 & 1687.33 & 8.91 \\
\hline & L. dejeni & 2 & 0.85 & 256.20 & 1.79 & 1 & 16.67 & 43.88 & 0.23 \\
\hline & Total & 236 & 100 & 14348.2 & 100.00 & 6 & 266.67 & 18936.9 & 100.00 \\
\hline
\end{tabular}




\section{Gonado-Somatic Index (GSI) and fecundity}

Gonad stage VI (running level) was the highest in levels of percent maturity for all species and at all sampling sites as compared to other stages (Figure 2). From the 933 Labeobarbus specimens sampled during peak-seasons, $64.95 \%$ were found at maturity stage of IV-VII. The rest $35.5 \%$ were immature (I-III) and the peak time of spawning was September (Figure 3).
The mean value of GSI is used to indicate peak time of reproductive season for spawning migratory species. Most of the time, males of the three dominant species had similar peak time which is September while female for L. brevicephalus peaked in October which is different from L. intermedius and L. nedgia that peaked in September and August, respectively.

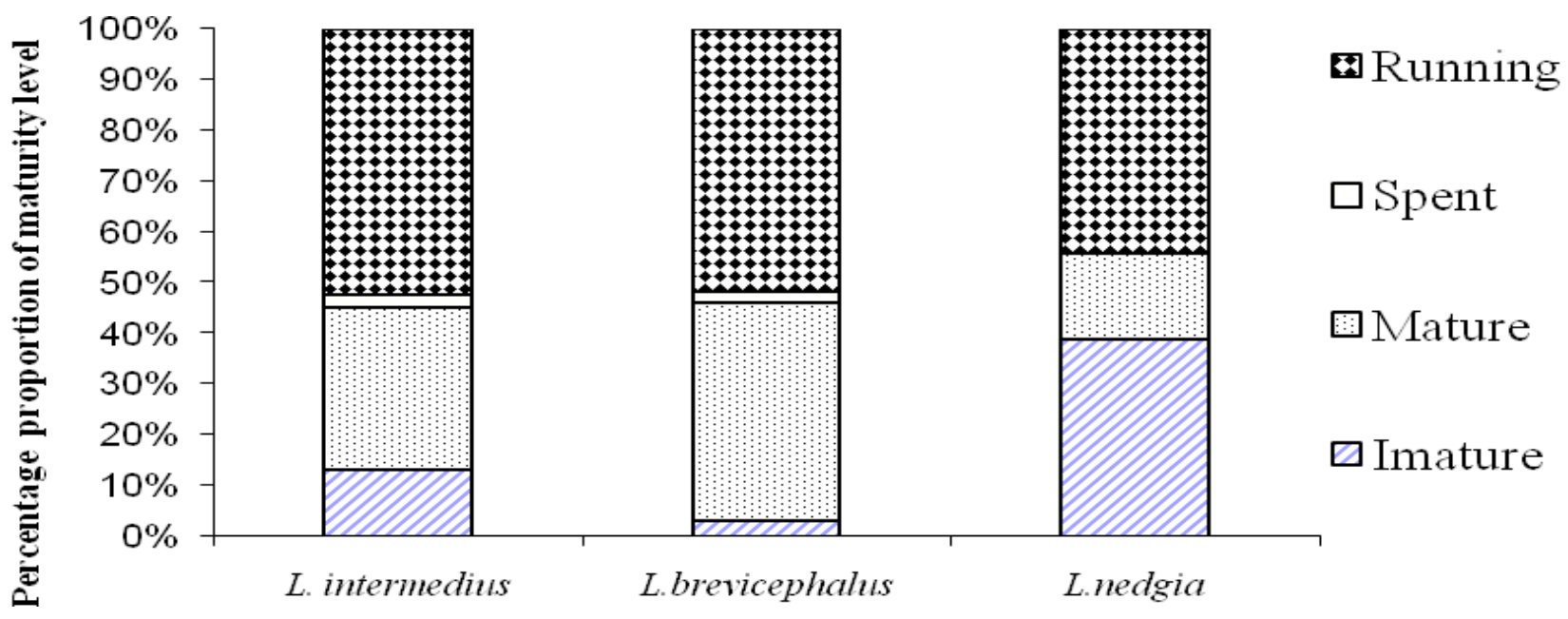

Figure 2. The proportion of maturity stages of the dominant Labeobarbus species.

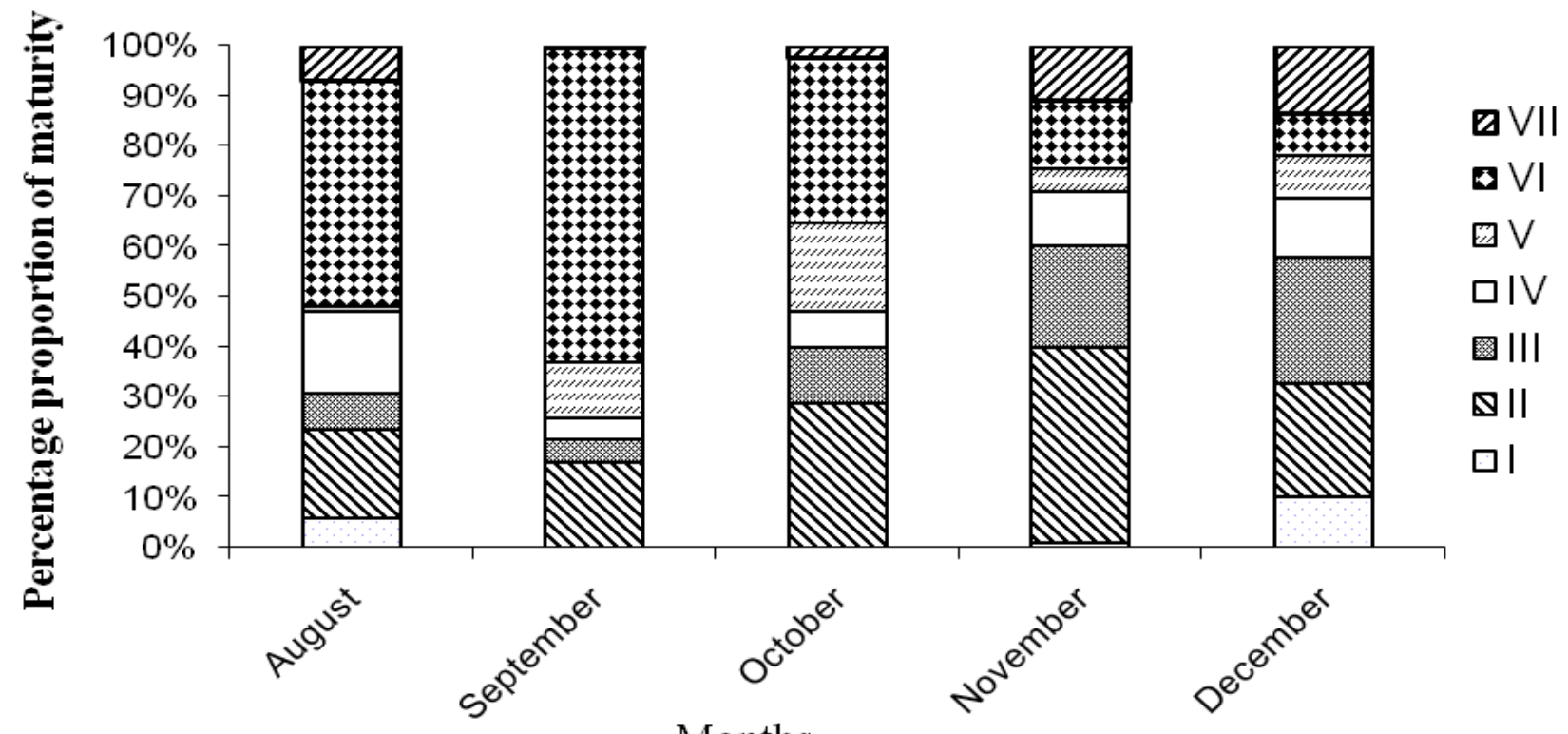

Months

Figure 3. Temporal distribution of maturity levels of Labeobarbus species in sampling rivers. 
Fecundity rates of the migratory Labeobarbus species were determined from a total of 141 specimens which mainly included L. intermedius (59), L. brevicephalus (67) and L. nedgia (15). Absolute (total) fecundity of the most dominant Labeobarbus species (L. intermedius, L. brevicephalus and L. nedgia) had linear relationship with their total gonad weight and fork length (Figures 4 and 5). Labeobarbus intermedius with fork length of 15 to $28 \mathrm{~cm}(21.79 \pm 0.44$ $\mathrm{cm}$, mean $\pm \mathrm{SE}$ ) had an absolute fecundity of 1265 to 13289 (mean fecundity of 5057), respectively and. Labeobarbus brevicephalus with fork length of 15 to
$29 \mathrm{~cm}(19.78 \pm 0.29 \mathrm{~cm}$, mean $\pm \mathrm{SE})$ had absolute fecundity ranging from 1225 to 9469 (mean fecundity of 3474), respectively. Labeobarbus nedgia with fork length 18 to $37 \mathrm{~cm}(25.14 \pm 1.42 \mathrm{~cm}$, mean \pm SE) had absolute fecundity ranging from 1448 to 14018 (mean fecundity of 5200), respectively.

The highest absolute fecundity (i.e., 18688 eggs) was recorded from L. truttiformis in Guanta River which had $58.4 \mathrm{~g}$ gonad weight. Absolute fecundity of each dominant migratory fish species had significant difference with their gonad weight ANOVA, $(p<0.0001)$ as shown in Figure 4.
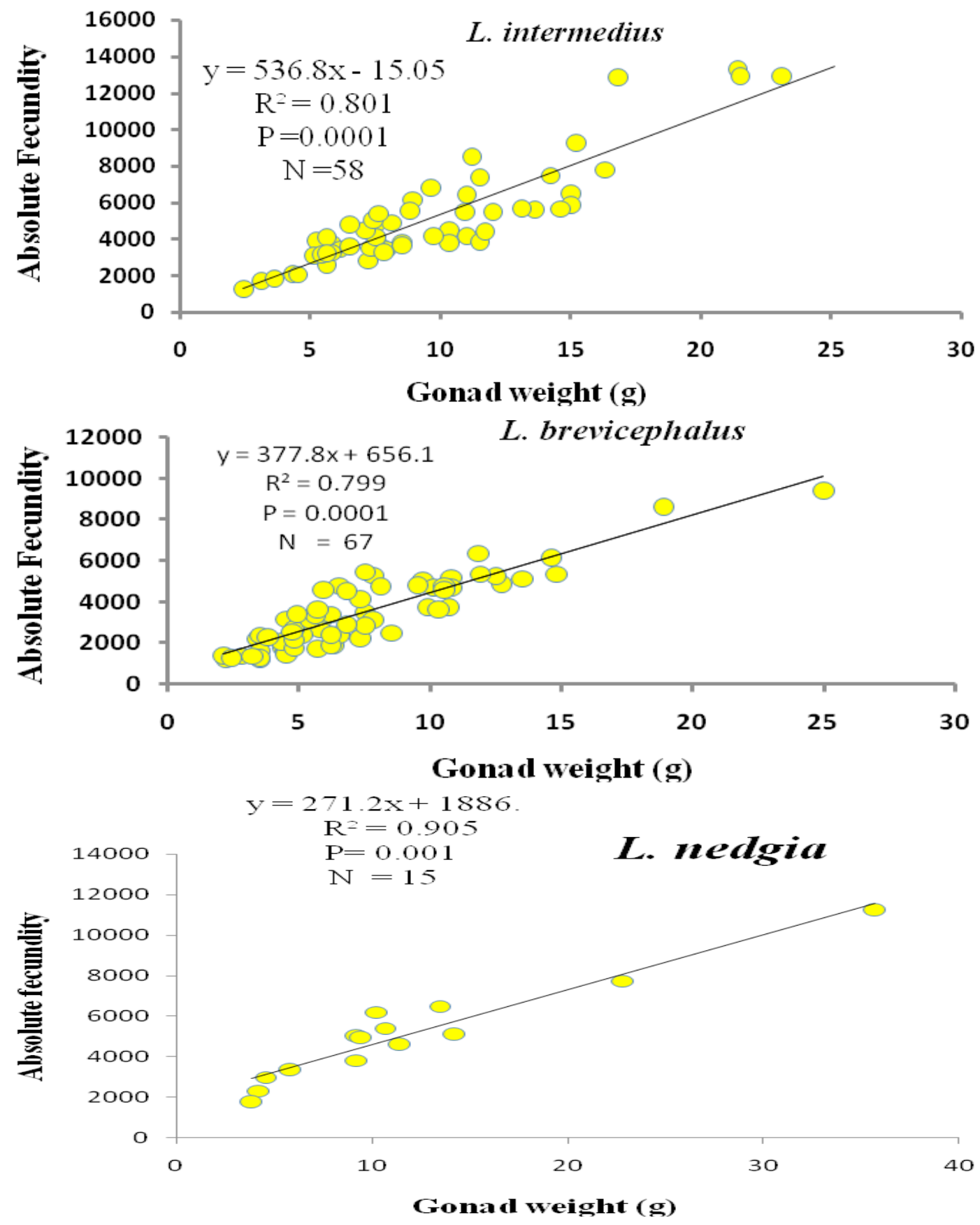

Figure 4. The relationship of absolute fecundity with gonad weight of the dominant 


\section{L. brevicephalus}
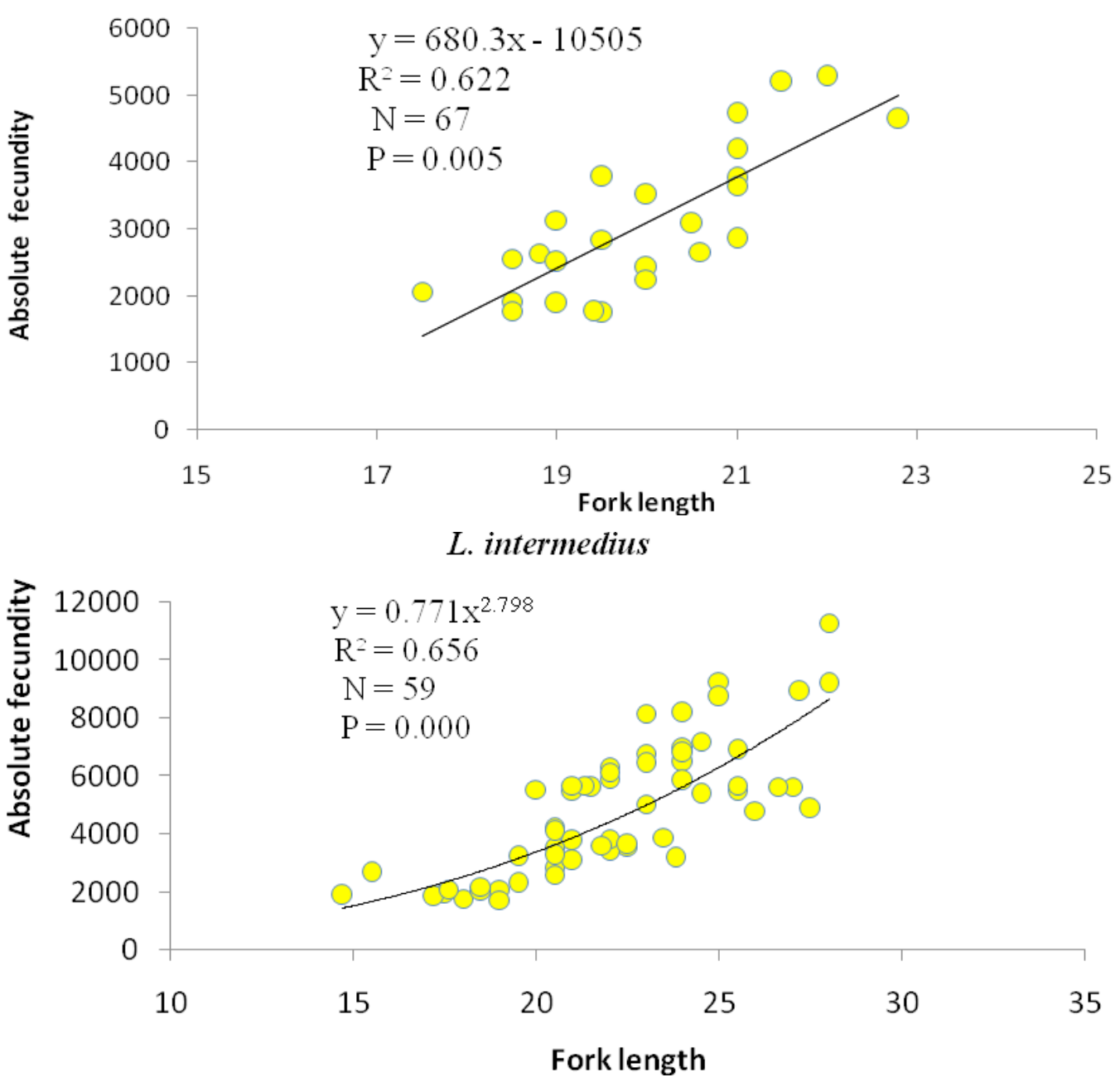

Figure 5. The relationship between absolute fecundity and fork length of L. brevicephalus and L. intermedius.

\section{Spatial and temporal spawning segregations}

Composition and distribution patterns of the three most abundant Labeobarbus species did not show significant difference in all sampling rivers except in the case of L. nedgia (one way ANOVA, $p>0.05$ ) (Table 4).

Table 4. Spatial segregation of the three most dominant Labeobarbus species in all sampling rivers (one way ANOVA).

\begin{tabular}{llll}
\hline \multirow{2}{*}{ River } & $\begin{array}{l}\text { L. brevicephalus }(\mathrm{N}=277) \\
\text { Mean } \pm \text { S.E }\end{array}$ & $\begin{array}{l}\text { L. intermedius }(\mathrm{N}=507) \\
\text { Mean } \pm \text { S.E }\end{array}$ & $\begin{array}{l}\text { L. nedgia }(\mathrm{N}=121) \\
\text { Mean } \pm \text { S.E }\end{array}$ \\
\hline Chibirna & $9.4 \pm 4.43$ & $37.8 \pm 6.02$ & $8.2 \pm 2.20^{\mathrm{b}}$ \\
Guanta & $14.6 \pm 7.15$ & $16.2 \pm 4.59$ & 0.00 \\
Qimon & $31.5 \pm 9.89$ & $28.3 \pm 14.50$ & $.3 \pm .25^{\mathrm{c}}$ \\
Shini & $7.8 \pm 4.59$ & $31.0 \pm 7.82$ & $19.8 \pm 8.23^{\mathrm{a}}$ \\
Total & $15.4 \pm 5.07$ & $28.2 \pm 4.28$ & $6.7 \pm 2.55$ \\
\hline P value & 0.398 & 0.318 & 0.01 \\
\hline
\end{tabular}


Spatial and temporal composition of the most abundant Labeobarbus species in all sampling rivers (Qimon, Guanta, Shini and Chibirna) is given in Table 5. Main breeding seasons were August, September and October and among these breeding months September was the most peak season for most of male Labeobarbus species.

\section{DISCUSSION}

\section{Abiotic factors and Spawning grounds}

All biological functions of living organisms in aquatic ecosystem such as growth, reproduction,

Table 5. Spatial and temporal segregation of the dominant Labeobarbus species ( $\mathrm{x}^{2} \mathrm{rXc}$ contingency table).

\begin{tabular}{llllll}
\hline \multirow{2}{*}{ Species } & \multicolumn{5}{c}{ Spatial distribution } \\
\cline { 2 - 6 } & Chibirna & Guanta & Qimon & Shini & Total \\
\hline L. brevicephalus & $47^{\mathrm{a}}$ & $73^{\mathrm{b}}$ & $126^{\mathrm{b}}$ & $31^{\mathrm{a}}$ & 277 \\
L. intermedius & $189^{\mathrm{a}}$ & $81^{\mathrm{b}}$ & $113^{\mathrm{b}}$ & $124^{\mathrm{b}}$ & 507 \\
L. nedgia & $41^{\mathrm{a}}$ & 0 & 1 & $79^{\mathrm{c}}$ & 121 \\
\hline Total & 277 & 159 & 247 & 234 & 917 \\
\cline { 2 - 6 } Species & & Temporal distribution & & \\
\cline { 2 - 6 } & August & September & October & November & December \\
\cline { 2 - 6 } L. brevicephalus & $25^{\mathrm{a}}$ & $166^{\mathrm{c}}$ & $33^{\mathrm{a}, \mathrm{b}}$ & $18^{\mathrm{a}}$ & $35^{\mathrm{b}}$ \\
L. intermedius & $94^{\mathrm{a}}$ & $180^{\mathrm{b}}$ & $95^{\mathrm{a}}$ & $64^{\mathrm{a}}$ & $74^{\mathrm{a}}$ \\
L. nedgia & $14^{\mathrm{a}}$ & $60^{6}$ & $21^{\mathrm{a}}$ & $16^{\mathrm{a}}$ & $10^{\mathrm{a}}$ \\
\hline Total & 140 & 408 & 149 & 101 & 119 \\
\hline
\end{tabular}

Note: Same superscript letters in a row indicates non-significant difference among each other at 0.05 and Numbers indicate absolute numbers of specimens

Labeobarbus intermedius was the first species to migrate to the upstream sites of Shini River starting from the second week of August and but its catch was higher at the end of September (fourth week). Labeobarbus brevicephalus and L. nedgia were the last species to migrate to Shini and Chibirna Rivers. Labeobarbus megastoma and L. truttiformis were caught rarely from Qimon and Guanta Rivers and reach peak during October and August, respectively. feeding and sexual maturity were determined by abiotic factors (Murdoch and Martha, 1999). The study indicated that all studied tributary rivers had different physico-chemical parameters due to different watershed, anthropogenic activities like sand mining in upstream of the rivers, and natural environmental variability. According to Wassie Anteneh et al. (2005) and Shewit Gebremedhin et al. (2012), Megech and Arno-Garno Rivers are the 
main preferable sites for Labeobarbus spawning, the same to that Chibirna, Shini and Qimon Rivers were depicted in current study while Guanta River had less fish diversity as well as least number of spawning migratory species. Highly oxygenated water and gravel beds are general requirements for Labeobarbus spawning due to their critical importance in the development of eggs and larvae (Skelton et al., 1991; Rodriguez-Ruiz and Granado Lorencio, 1992; Baras et al., 1996; Baras, 1997; Abebe Getahun et al., 2008). Similar assessment was made by de Graaf (2005) in Gumara, Gilgel Abbay, Ribb and Gelda Rivers that had different physical parameters such as temperature and secchi disk, showing strong seasonal patterns. In contrast with the report of Eshete Dejen (2004), Lake Tana mean value of conductivity was $\left(132.8 \mu \mathrm{s} \mathrm{cm}^{-1}\right)$ which is much lower than conductivity value of the studied tributary rivers. This might be due to the different anthropogenic activities and environmental differences in Lake Tana and its tributary rivers.

In general, the variability of physico-chemical parameters in flowing rivers had strong relations with biological functions of any aquatic organism. Recently, Lake Tana fish production is declining as compared to the last ten years due to environmental and anthropogenic factors (Dereje Tewabe, 2013). This result is in line with Jamu et al. (2003) who reported similar results on some physico-chemical parameters that showed significant predictors of the migration dynamics and reproductive status of two Barbus species from Lake Chilwa basin (Malawi).

Low abundance and diversity of migratory fish species were recorded in the present study as compared to the previous studies which might indicate the decline of the migratory fish in the lake. Overfishing at Lake Tana and also degradation of spawning grounds and routs were might be main cause of the decline of spawning migratory species.
In agreement with Dereje Tewabe (2013) the main cause for the decline of the migratory fish species is fishing pressure at spawning grounds with illegal monofilament introduction.

\section{Gonado-Somatic Index (GSI \%) and Fecundity}

Previous studies on reproductive segregation of Labeobarbus species of Lake Tana including Palstra et al. (2004), de Graaf (2005), Wassie Anteneh et al. (2005) and Shewit Gebremedhin et al. (2012) have reported the spawning aggregations of ripe and running fishes. According to Wassie Anteneh et al. (2005), L. intermedius reproduce throughout the year and it is both riverine and lacustrine, whereas in the current study, L. intermedius has similar reproductive season (GSI\%) with other spawning migratory Labeobarbus species. During the end of spawning season high number of spent maturity levels and low abundance of fish specimens were recorded. Similar results were reported by de Graaf et al. (2005) that stated the peak-spawning season for Labeobarbus species in Lake Tana to be from August to October.

The fecundity rate of most dominant Labeobarbus species was in line with the results made by Mohammed Omer (2010) that studied Labeobarbus species at the head of Blue Nile River. Lower fecundity value was recorded in this study ( $L$. brevicephalus, 1225 eggs) and this absolute fecundity value was lowest as compared to other cyprinids, Barbus grypus (16000-235784 eggs), Labeo senegalensis (12948-74832 eggs) and Labeo parvus (8723-124363 eggs) (Claudine et al., 2013). This difference might be due to difference in genetic variability, food availability and other environmental conditions.

The relationship of fork length and total body weight with absolute fecundity was linear for $L$. brevicephalus. This is in line with the report of 
Dagnew Mequanent (2012). This indicates that absolute fecundity is directly related to the body size of the migratory species. According to Claudine et al. (2013) gonad weight is better correlated with reproductive capacity than fish size and fish species with these types of relationship have rapid growth and high fertility. Such characteristics are important for aquaculture development. According to Oliva Paterna et al. (2002) fast growth, high fecundity and early maturity are the characteristics of unstable environments.

\section{CONCLUSION}

Lake Tana Labeobarbus species is a unique species flock that was found highly threatened due to fishing activities and degradation of the environment. Small tributary rivers of Lake Tana (Shini, Qimon, Chibirna, and Guanta Rivers) are main spawning grounds however human interface (unregulated sand mining and irrigation) have influenced these spawning grounds. Numerous table size Labeobarbus species were caught from Shini and Chibirna Rivers during sampling seasons, but during the dry season no fish could be seen due to water withdrawal for irrigation. The communities who are living nearby the water bodies are not aware of when and where fish breed. That is why local inhabitants around Qimon and Guanta Rivers have the tradition of capturing fish for consumption and marketing during the peak spawning season and they use traditional fishing methods (using hooks and lines and monofilament gillnets). The time and sites of setting fishing gears are highly correlated with the time of segregation and aggregation of riverine migratory Labeobarbus species. Therefore, at least during peak time of spawning season, specific spawning grounds should be closed from fishing activities as well as irrigation canals have to be integrated and harmonized with river biodiversity. The community, governmental and non-governmental organizations, policy makers and fishers should be aware of the reproductive strategy of the migratory fishes and potential human impacts on them for sustainable utilization of the resources.

\section{ACKNOWLEDGEMENTS}

We are greatly indebted to Rufford Foundation, UK and Blue Nile Water Institute, Bahir Dar University for provision of funds for this study. The kind collaboration of the staff members of Bahir Dar Fish and Other Aquatic Life Research Centre in providing materials needed for the study is very much appreciated.

\section{REFERENCES}

Abebe Getahun. (2002.) The Nile basin: Riverine fish and fisheries, Department of Biology Addis Ababa University, Ethiopia .19pp.

Abebe Getahun, Eshete Dejen and Wassie Anteneh. (2008). Fishery studies of Ribb River, Lake Tana Basin, Ethiopia. Final Report E1573, Vol. 2, Ethiopian Nile Irrigation and Drainage Project Coordination Office, Ministry of Water Resources, Ethiopia.

Akewake Geremew. (2007). Taxonomic revision, relative abundance, and aspects of the Biology of some species of the genus Garra, Hamilton 1922 (Pisces: Cyprinid) in Lake Tana, Ethiopia. MSc. Thesis, Addis Ababa University, Ethiopia.

Baras, E. (1997). Environmental determinants of residence area selection and long term utilisation in a shoaling teleost, the common barbel (Barbus barbus L.). Aquatic Living Resources 10: 195206.

Baras, E., Philipart, J.C., and Nindaba, J. (1996). Importance of gravel bars as spawning grounds and nurseries for European running water cyprinids. $2^{\text {nd }}$ International Symposium on Habitat Hydraulics, volume A: 367-378. 
Claudine, T.T., Minette, T.E and Joseph, T. (2013).

Reproductive Strategy of Labeobarbus batesii (Teleostei: Cyprinidae) in the Mbô Floodplain Rivers of Cameroon, International Journal of Zoology http://dx.doi.org/10.1155/2013/452329.

de Graaf, M., Machiels, A. M., Tesfaye Wudneh and Sibbing, F. A. (2004). Declining stocks of Lake Tana's endemic Barbus species flock (Pisces; Cyprinidae): natural variation of human impact? Biological Conservation 116: 277-287.

de Graaf, M., Nentwich, E.D., Osse, J.W.M and Sibbing, F.A. (2005). Lacustrine spawning, a new reproductive strategy among 'large' African cyprinid fishes? Journal of Fish Biology 66:2141236.

Dereje Tewabe. (2013). Status of Lake Tana commercial fishery, Ethiopia. ABC Research Alert 1:1-16.

Eshete Dejen, Osse, J.W.M and Sibbing, F.A. (2003). Ecological position of 'small barbs' and their potential for fisheries: An option to reduce fishing pressure on 'large barbs' of Lake Tana (Ethiopia)? Aquatic Ecosystem Health and Management 6: 337-342.

Eshete Dejen, Vijverberg, J., Nagekerke, L.A.J and Sibbing, F.A. (2004). Temporal and spatial distribution of micro crustacean zooplankton in relation to turbidity and other environmental factors in large tropical lake (Lake Tana, Ethiopia). Hydrobiology 513: 39-49.

Jamu, D. M., Chimphamba, J. B and Brummett, R. E. (2003). Land use and cover changes in the Likangala catchment of the Lake Chilwa basin, Malawi: implications for managing a tropical wetland. African Journal of Aquatic Science 28: 123-135.

Kolding, J. (1999). Pass gear: A data base Package for experimental or artisanal fishery data from passive gears. An introductory manual University of Bergen Dept. of Fisheries and Marine Biology.

Murdoch, T and Martha, C. (1999). The Stream Keeper's Field Guide: Watershed Inventory and Stream Monitoring Methods. A Product of the Adopt-A-stream Foundation. Everett, WA, 296 pp.

Nagelkerke, L.A.J and Sibbing, F.A. (1996). Reproductive segregation among the large barbs (Barbus intermedius complex) of Lake Tana, Ethiopia. An example of intra lacustrine speciation? Journal of Fish Biology 49: 12441266.

Nagelkerke, L. A. J. (1997). The barbs of Lake Tana, Ethiopia: morphological diversity and its implications for taxonomy, trophic resource partitioning and fisheries. $\mathrm{PhD}$ Thesis, Wageningen University, The Netherlands.

Nagelkerke, L. A. J and Sibbing, F. A. (2000). The large barbs (Barbus spp., Cyprinidae, Teleostei) of Lake Tana (Ethiopia), with a description of a new species, Barbus osseeinsis. Netherlands Journal of Zoology 50: 179-214.

Palstra, A.P., de Graaf, M and Sibbing, F.A. (2004). Riverine spawning in a lacustrine cyprinid species flock, facilitated by homing? Animal Biology 54: 393-415.

Rzóska, J. (1976). Lake Tana, head water of the Blue Nile. In The Nile, Biology of an Ancient River (Rzóska, J., ed), pp. 223-232. The Hague: Dr Junk Publishers.

Rodriquez-Ruiz, A. and Granado-Lorencio, C. (1992). Spawning period and migration of three species of cyprinids in a stream with Mediterranean regimen (SW Spain). Journal of Fish Biology 41: 545-556. 
Sanyanga, R.A. (1996). Variation in abundance of Synodontis zambezensis (Pisces: Mockokidae) Peters 1852, in the shore fishery of Lake Kariba. Fisheries Research 26:171-186.

Shewit Gebremedhin, Minwyelet Mingist, Abebe Getahun and Wassie Anteneh (2012). Spawning migration of Labeobarbus species of Lake Tana to Arno-Garno River, Lake Tana sub-basin, Ethiopia. SINET: Ethiopina Journal of Science 35:95-106.

Skelton, P.H., Tweddle, D. and Jackson, P. (1991). Cyprinids of Africa. In: Cyprinid Fishes, Systematics, Biology and Exploitation (Winfield, I. J. and Nelson, J. S., eds), pp. 211-233. London: Chapman and Hall.

Tómasson,T., Cambray, J.A. and Jackson, P. B. N. (1984). Reproductive biology of four large riverine fishes (Cyprinidae) in a man-made lake, Orange River, South Africa. Hydrobiologia 112: 179-195.

Wassie Anteneh (2005). The spawning migration and reproductive biology of Labeobarbus (Cyprinidae: Teleostei) of Lake Tana to Dirma and Megech Rivers Ethiopia. MSc thesis, Addis Ababa University, Addis Ababa, Ethiopia. 